\title{
オーステナイト系ステンレス鋼中の加工誘起 マルテンサイトの組織形態と磁気特性の相関
}

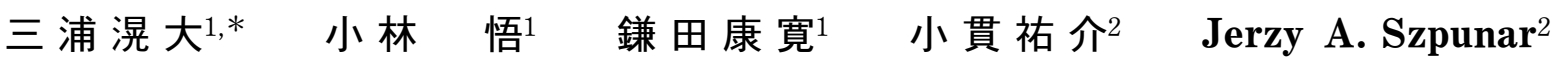

1岩手大学工学部

2サスカチュワン大学工学部

J. Japan Inst. Met. Mater. Vol. 78, No. 10 (2014), pp. 375-380

(C) 2014 The Japan Institute of Metals and Materials

\section{Relationship between Morphology of Strain-Induced Martensite Phase and Magnetic Properties in Austenitic Stainless Steels}

Kodai Miura $^{1, *}$, Satoru Kobayashi ${ }^{1}$, Yasuhiro Kamada ${ }^{1}$, Yusuke Onuki ${ }^{2}$ and Jerzy A. Szpunar ${ }^{2}$

${ }^{1}$ Faculty of Engineering, Iwate University, Morioka 020-8551

${ }^{2}$ Department of Mechanical Engineering, University of Saskatchewan, Saskatoon SK S7N 5A9, Canada

We have performed high-sensitivity magnetic measurements for tensile-deformed SUS304-type austenitic stainless steel to elucidate a relationship between morphology of martensite particles and structure-sensitive magnetic hysteresis properties. A monotonic increase of the volume fraction of martensite phase up to $14.3 \%$ through strain-induced martensitic transformation was observed, while coercivity exhibits a maximum at around $4.3 \%$ fraction. Measurements of coercivity varying the magneticfield direction against tensile direction revealed anisotropy in angular dependence of coercivity that becomes weaker with the progress of plastic deformation. These observations were explained as due to a change of the size and anisotropy in shape of martensite phase with deformation. [doi:10.2320/jinstmet.JAW201405]

(Received April 18, 2014; Accepted June 26, 2014; Published October 1, 2014)

Keywords: magnetic hysteresis, austenitic stainless steels, ferromagnetic martensite, plastic deformation, coercivity

\section{1. 緒言}

オーステナイト系ステンレス鋼は高強度，高耐食性，非磁 性の特徵を持つため, 原子力発電所の配管, 化学プラントの 構造材料などに数多く使用されている. これら構造物の保全 のためには，材料非破壞評価技術が不可欠であり，簡便かつ 有効な評価方法が求められている.

オーステナイト系ステンレス鋼は経年劣化等により応力が 加わると加工誘起マルテンサイト変態を引き起こす. 非磁性 の FCC 構造のオーステナイトから強磁性の BCC 構造のマ ルテンサイトへと变態するため1-3), 磁性を用いた非破壊評 価が有効である. 従来の非破壊評価として, 飽和磁化および 初期磁化率を用いたマルテンサイト量の評価が行われてき た4). 一方, 保磁力などのヒステリシス特性に着目すること でマルテンサイト相の体積分率の他, その体積分率の増加に 伴う保磁力の変化からマルテンサイト相の結晶粒径の評価が 可能だと近年報告されている5). しかし，その系統的研究は 行われて抢らず, 磁気ヒステリシス特性とマルテンサイトの 形態の相関は詳しく理解されていない, 本研究では, 引張変 形した SUS304 鋼について, 引張方向に対する保磁力の励

\footnotetext{
* 岩手大学大学院生 (Graduate Student, Iwate University)
}

磁方向依存性に着目し, マルテンサイト相の形態とその相関 を系統的に調査したので報告する。

\section{2. 実 験 方 法}

本研究では商業用オーステナイト系ステンレス鋼の SUS304 を使用した. 化学組成は, Table 1 に示す. $3 \mathrm{~mm}$ 厚の熱間圧延材から放電加工機により 5 号引張試験片を切 り出した. 引張試験は SHIMADZU AG-250kNG を用い て, 室温にて, ひずみ速度 $5.6 \times 10^{-4} \mathrm{~s}^{-1}$ で行った. Fig. 1 にSUS304 に打ける真応力一真ひずみ曲線を示す.

引張試験後, 試験片から飽和磁化測定用に $1 \mathrm{~mm} \times 1 \mathrm{~mm}$ $\times 3 \mathrm{~mm}$ の試料と, 保磁力の方向依存性測定用に $\phi 4.5 \mathrm{~mm}$ の試料を試験片から切り出した。磁気測定には SQUID (Superconducting QUantum Interference Device)磁束計 (Quantum Design MPMS5L)を使用した。温度 $300 \mathrm{~K}$ にお いて, 最大印加磁場 $2400 \mathrm{kA} \cdot \mathrm{m}^{-1}$ の範囲で行った. Fig. 2

Table 1 Chemical compositions of SUS304 austenitic stainless steel.

\begin{tabular}{ccccccccc}
\hline Element & $\mathrm{C}$ & $\mathrm{Si}$ & $\mathrm{Cr}$ & $\mathrm{Ni}$ & $\mathrm{Mn}$ & $\mathrm{P}$ & $\mathrm{S}$ & $\mathrm{Fe}$ \\
\hline Mass\% & 0.08 & 0.6 & 18.9 & 8.2 & 1.3 & 0.12 & 0.09 & Bal. \\
\hline
\end{tabular}




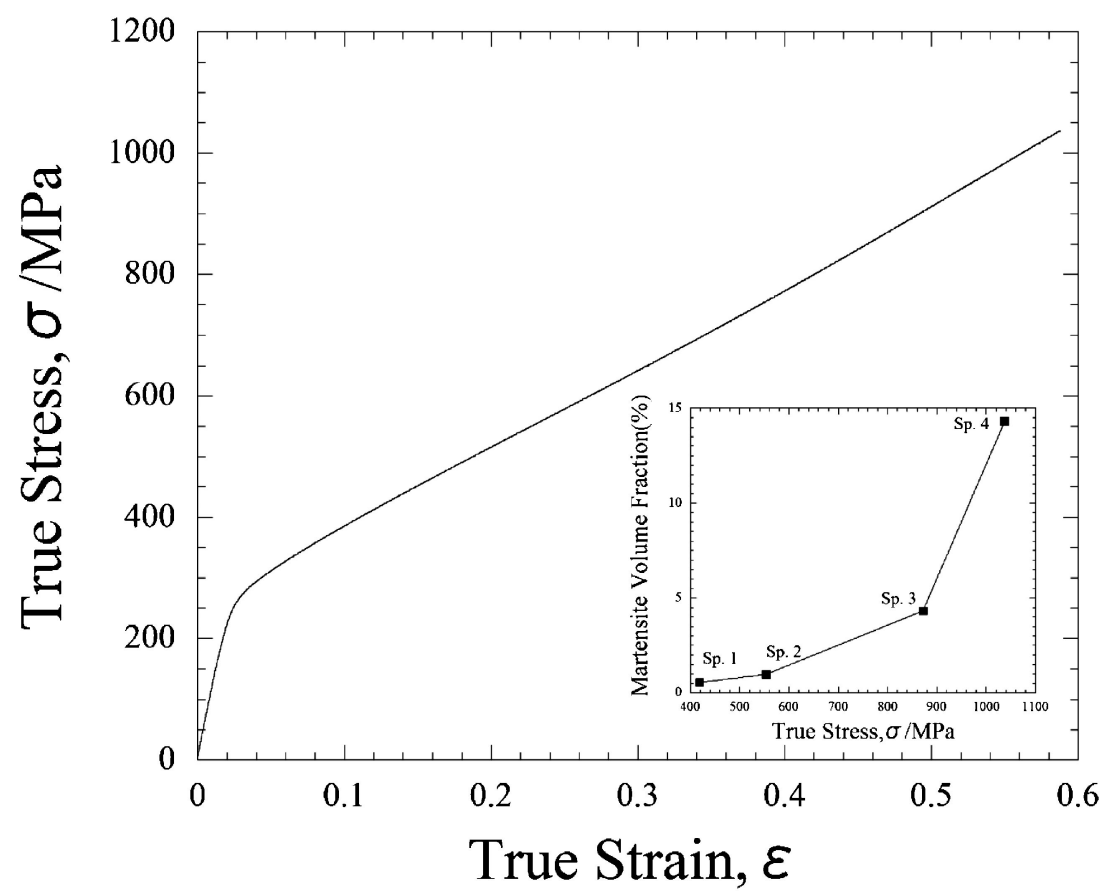

Fig. 1 True stress vs true strain curves obtained by uniaxial tensile tests. The inset shows martensite volume fraction in SUS304 as a function of true stress.

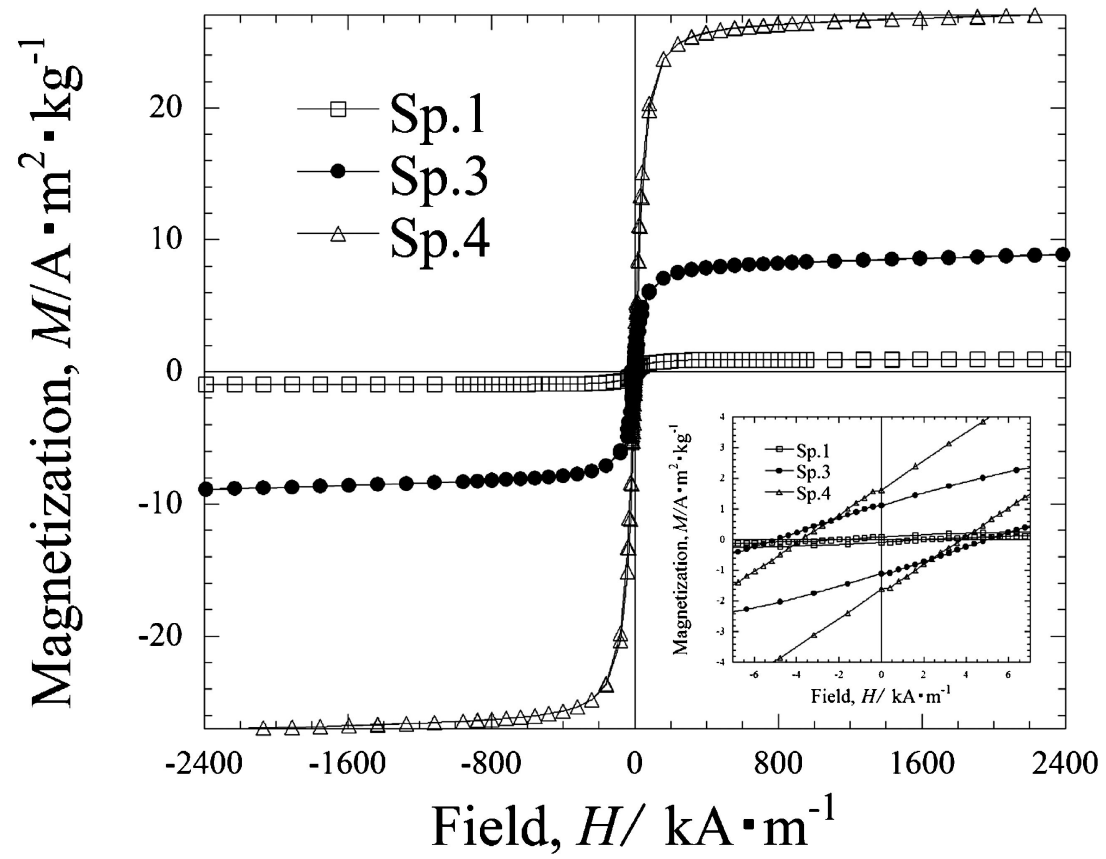

Fig. 2 Magnetization curves measured along the tensile direction for Sp.1, Sp.3 and Sp.4 samples. The inset shows their enlargement around zero field.

に引張変形応力が $419 \mathrm{MPa}, 872 \mathrm{MPa}, 1037 \mathrm{MPa}$ に抢ける 磁化曲線を示す．飽和磁化の值は，高磁場側 (2400〜800 $\mathrm{kA} \cdot \mathrm{m}^{-1}$ )の磁化曲線を 0 磁場の值に外插して求めた。 マル テンサイト体積分率 $100 \%$ を $154 \mathrm{~A} \cdot \mathrm{m}^{2} \cdot \mathrm{kg}^{-1}$ とし6)，各試料 の飽和磁化から体積分率を推定した. Fig. 1 挿入図に真応力 に対するマルテンサイト体積分率の変化を示す．変形と共に 体積分率は増加し，変形応力 $900 \mathrm{MPa}$ 近傍加急激に上昇 すると $14.3 \%$ まで達した。これらの結果を Table 2 にまと
Table 2 Results of tensile test and saturation magnetization.

\begin{tabular}{lccc}
\hline & $\begin{array}{c}\text { True stress, } \\
\sigma / \mathrm{MPa}\end{array}$ & $\begin{array}{c}\text { True strain, } \\
\varepsilon\end{array}$ & Martensite volume fraction \\
$(\%)$
\end{tabular}


めて示す。ここでは，マルテンサイト体積分率 $0.56 \%$, 0.98\%，4.3\%，14.3\%の試料をそれぞれ，Sp.1，Sp.2，Sp.3， Sp.4 とした.

磁気特性と集合組織および微細組織の関係を調べるために X 線回折法による集合組織測定, 光学顕微鏡観察を行った.

引張試験片中央部から $\phi 18 \mathrm{~mm}$ の円盤試料を切り出し, エメリー紙による研磨を行った. その後, 電圧 $30 \mathrm{~V}$ にて電 解研磨を施し測定を行った。研磨液は, 酢酸 : 過塩素酸 $=$ 9: 1 を使用した。実験装置は X 線回折 (Bruker D8 Discover: $\mathrm{CrK} \alpha$ 線)を使用した。測定データは Resmat Textools ${ }^{7)}$ で 解析を行い評価した.オーステナイト相において， $\{111\}$, $\{100\}$, マルテンサイト相では, $\{110\},\{100\}$ の正極点図を それぞれ作成した。これら正極点図をもとに結晶方位分布関 数 $(\mathrm{ODF})$ を計算し, 引張軸の結晶方位分布を表わす逆極点 図を作成した。軸密度は平均軸密度を 1 として, その倍数 で表現した。

光学顕微鏡観察用試料は, エメリ一紙による研磨, 電解研

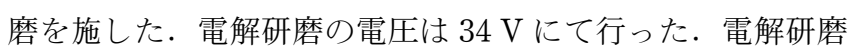
後, 表面に水性磁性コロイドを塗布することで, マルテンサ イト相の判別を行った.

\section{3. 実 験 結 果}

\section{1 保磁力の励磁方向依存性}

Fig. 2 にSp.1, Sp.3, Sp.4 におけるマルテンサイト体積分 率を変化させた時の磁化曲線を示す。マルテンサイト体積分 率の増加に伴い, 飽和磁化の増加が観測された. Fig. 2 挿入 図には, Fig. 2 の磁化曲線に抢ける保磁力近傍の拡大図を示 す。保磁力はマルテンサイト体積分率 $4.3 \%$ に至るまで増加 し，その後 $14.3 \%$ に達するまで減少するに至った. Fig. 3
にSp.4 における引張方向に対して励磁方向を変化させた時 の磁化曲線を示す。ここでは $0^{\circ}$ 方向を引張方向と定義し た. 引張方向に磁化した場合， $0 \mathrm{kA} \cdot \mathrm{m}^{-1}$ 近傍の磁化はその 垂直方向よりも高い傾向が観測された. Fig. 3 挿入図には, Fig. 3 の磁化曲線に抢ける保磁力近傍の拡大図を示す. 励磁 方向と引張方向との成す角度の増加に伴い保磁力が増加する 傾向が観測された。この傾向はすべての試料で観測された.

各試料において引張方向に対して励磁方向を変化させ，そ の角度に抢ける保磁力のプロットを Fig. 4 に示す. 保磁力 は $0^{\circ}$ (引張方向)に捛いて最小值を取り, 垂直方向に近付く につれて単調に増加し，90で最大值を取った. Sp.1〜Sp.4 の最大值は最小值の約 3.1 倍, 1.7 倍, 1.5 倍, 1.5 倍の値を 有していた. この保磁力の異方性 (最大值と最小值の比)はマ ルテンサイト体積分率の増加に伴い減少する傾向が観測され た. さらに, 保磁力の角度依存性は, マルテンサイト体積分 率が増加しても顕著な変化は観測されなかった.

マルテンサイト体積分率の増加に対する保磁力の変化を調 べるために，体積分率に対して，各試料におけるすべての角 度の保磁力を平均した值のプロットをFig. 5 に示す. 保磁 力はマルテンサイト体積分率 $4.3 \%$ まで増加し, その後 14.3\%に至るまで減少した。この結果は, Fig. 2 の結果とも 一致する. Sp.3の平均の保磁力は $6.0 \mathrm{kA} \cdot \mathrm{m}^{-1}$ を有し, Sp.1 と Sp.4の約 1.8 倍, 1.4 倍の值であった.

\section{$3.2 \mathrm{X}$ 線による集合組織の測定結果}

Fig. 6(a)，(b)にSp.4 におけるマルテンサイト相とオース テナイト相の引張軸の密度分布を表わす逆極点図をそれぞれ 示す、マルテンサイト相では $\langle 110\rangle に$ 軸密度の集積が観測さ れた。しかし，その強度は 1.1 と非常に低い值であった。一 方，オーステナイト相においては，〈001〉と〈111〉の 2 か所

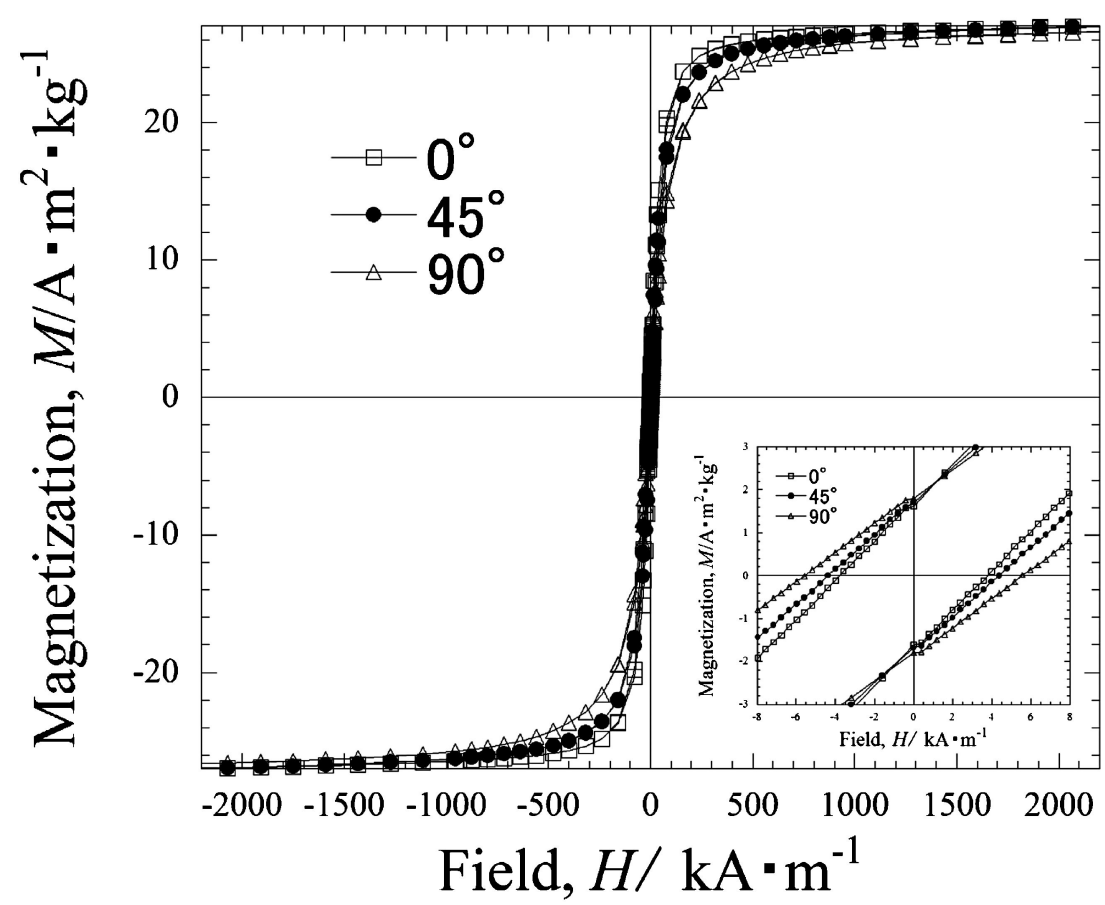

Fig. 3 Dependence of magnetization curves on magnetic-field direction for Sp.4 sample. The inset shows their enlargement around zero field. 


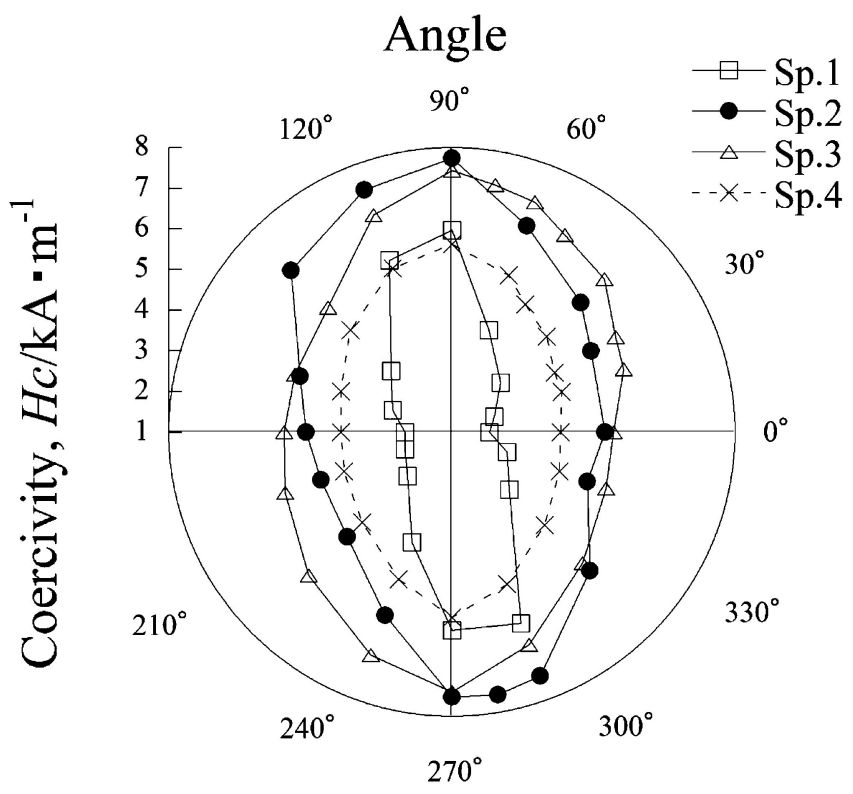

Fig. 4 Angular dependence of coercivity when magnetic-field direction changes against tensile direction. The zero angle corresponds to the tensile direction and angle denotes that between magnetic-field direction and tensile direction.

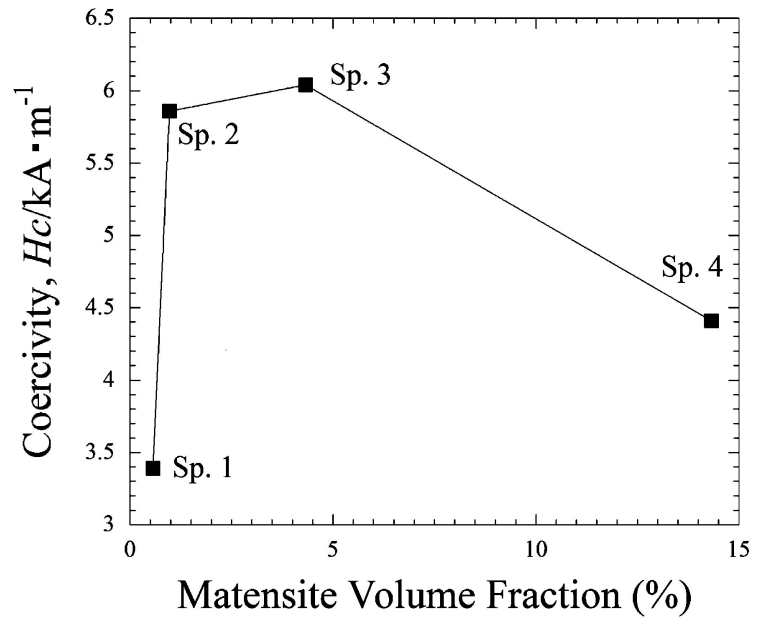

Fig. 5 Mean coercivity as a function of martensite volume fraction.

に軸密度の集積が観測された。これは典型的な FCC 金属の 変形集合組織であり，過去の報告とも一致する8,9).

\section{3 光学顕微鏡観察結果}

Fig. $7(\mathrm{a}) \sim(\mathrm{c})$ にSp.2, Sp.3, Sp.4 における光学顕微鏡画 像を示す. Fig. 7(a)では, 矢印に示したような板状のマル テンサイトが結晶粒内で 1 または 2 方向に配列しているこ とが観測された。（b)，(c)に拈いて, 変形の進行に伴い, 板 状マルテンサイトの領域が拡大していくことが分かった．さ らに，(c)では，矢印に示したようなブロック状のマルテン サイトも見られた。これらの結果は過去の報告とも一致す る10).

Fig. 8 に, 板状マルテンサイトと引張軸の成す角度の分布 を示す，縦軸の頻度は，各角度で観察された板状マルテンサ イトの数をこの総数で割った值である. 変形の進行に伴い,

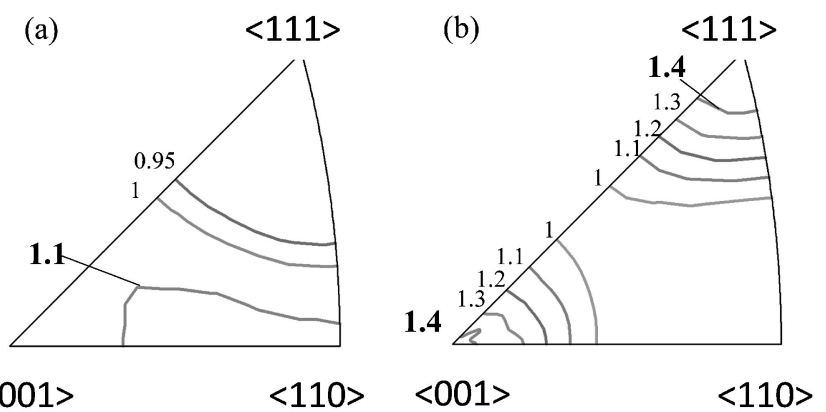

Fig. 6 Inverse pole figures of tensile direction for Sp.4 in (a) martensite phase and (b) austenite phase.

(a)

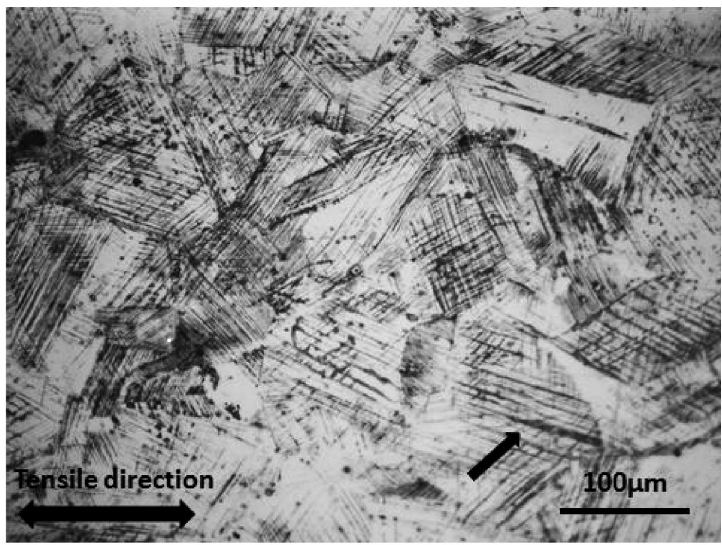

(b)

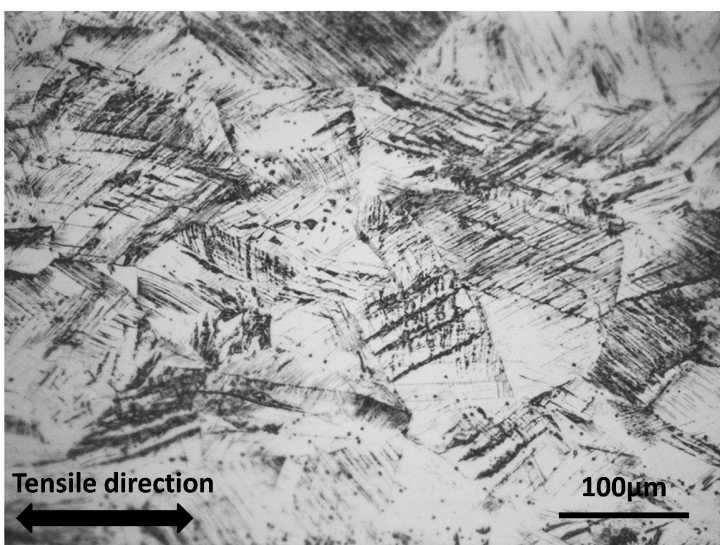

(c)

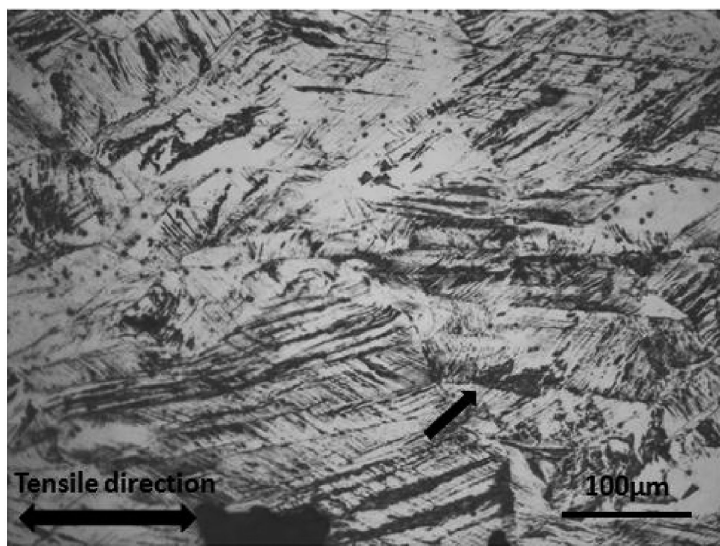

Fig. 7 Optical micrographs for (a) Sp.2, (b) Sp.3 and (c) Sp.4. In (a), arrow indicates plate martensite, in (c), arrow indicates blocky martensite. 


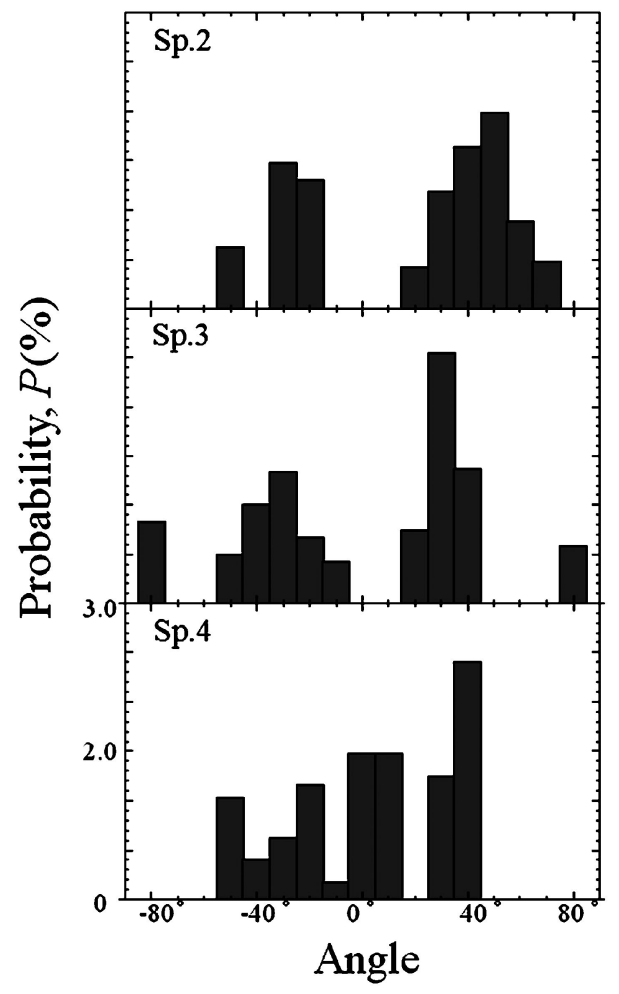

Fig. 8 Angular distribution of martensite phase. The angle formed by plate martensite and tensile direction.

頻度分布が低角側ヘシフトしていく傾向が観測された. Sp.2 では $40^{\circ} \sim 50^{\circ}, \mathrm{Sp} .3$ では $30^{\circ},-30^{\circ}$ に頻度の集中が観測さ れた. Sp.4においては， $-20^{\circ} \sim 20^{\circ}$ の範囲に頻度の集中が 見られた。

\section{4. 考察}

本研究では，オーステンサイト系ステンレス鋼の SUS304 鋼において引張变形を加え, 励磁方向を変化させた時の磁気 特性を調査した. Fig. 2 から, 変形に伴う飽和磁化の増加が 観測された. SUS304 鋼は一般的に応力が加わると, 結晶粒 界や双晶, 応力集中が起きる箇所でマルテンサイト変態を引 き起こすことが知られている1-3). マルテンサイト相は強磁 性を示すことから, Fig. 2 の飽和磁化の増加は, 本試料にお いてもマルテンサイト変態が生じていることを示している.

初めに集合組織抢よび微細組織と磁気特性について考察す る. Fig. 4 から, マルテンサイト体積分率が増加しても, 保 磁力の角度依存性は変化しないことが分かった. PérezBeniteza らによると, 変形により, 保磁力の角度依存性が 変化し, 最終的に引張方向の保磁力が小さくなる傾向が報告 されている11). 保磁力が引張方向で最小值を取ることは, 本研究の結果 (Fig. 4) とも一致するが, 角度依存性の变化は 観測されていない.したがって, SUS304 鋼において，オー ステナイト相の塑性変形とその変形に伴うマルテンサイト相 の核生成抢よびその合体 ${ }^{12)}$ が变形過程の主となっていると 考えられる.

X 線回折の結果 (Fig. 6) からは, マルテンサイト相では $〈 110 〉 の$ 軸密度の集積が観測された.しかし, その軸密度は
非常に弱く, 結晶回転による集合組織の形成はあまり生じて いないことが明らかとなった. 鉄の BCC 構造における磁化 容易軸は〈100〉であるが13)，〈100〉の軸密度の集積は観測さ れていない。したがって, 励磁方向に依存した保磁力の変化 は, 結晶方位分布と強い相関がないことを示している.

一方, Fig. 7 では, 板状マルテンサイトが観測され, 変形 に伴いマルテンサイト相の領域が拡大していくことが観測さ れた.このことから，マルテンサイト相の成長が Fig. 2 の 飽和磁化の増加に寄与していることが考えられる. 板状マル テンサイトは結晶粒内で 1 または 2 方向に配列しているこ とは，マルテンサイトがすべり線または双晶に沿って形成し ているためだと考えられる12).

Fig. 7 (c)に拈けるブロック状のマルテンサイトが観測さ れた.これは, 板状マルテンサイトが成長にすることで, 周 囲のマルテンサイト相と合体することで形成したと考えられ る. 板状マルテンサイトの成長とブロック状のマルテンサイ トの形成は, Fig. 5 の保磁力角度依存性の異方性の減少に寄 与していると推測される.

次にマルテンサイト体積分率に対する保磁力の増減 (Fig. 5) と保磁力の角度依存性 (Fig. 4)について考察する. Herzer は, 磁性相の結晶粒サイズの変化に伴い保磁力も変化するこ とを報告している14) . 結晶粒が非常に小さく単磁区構造を 持つ場合，粒のサイズの増加に伴い保磁力は増加する。一 方, 結晶粒が多磁区構造を持つ場合は, 粒のサイズの増加に 伴い保磁力は減少する. さらに, マルテンサイト体積分率の 増加に伴う保磁力の単調な減少は Kobayashi らによっても 報告されている5)。これらのことから, 板状マルテンサイト の成長 (Fig. 7) は, 飽和磁化の増加抢よび保磁力の減少に寄 与していると考えられる. さらに, Fig. 5 では保磁力の増加 が観測された.これは, マルテンサイト相が単磁区構造を持 っているためだと考えられが，磁区観察は行っておらず，今 後さらなる調査が必要である.

マルテンサイト相が多磁区構造を持つことを仮定し, Fig. 4 の保磁力の角度依存性について議論する. Fig. 4 より保磁 力は引張方向に拈いて最小值，90方向で最大值を取ること が分かった．多磁区構造を持つ場合，ブロッホ磁壁の面積に 対して結晶粒界, 転位といったピニングサイトの密度が増加 すると，それに伴い保磁力は増加することが知られてい る15). Fig. 7, Fig. 8 より, オーステナイト母相に板状マル テンサイトが形成し, 変形に伴い引張軸との成す角度が小さ くなる傾向が観測された. 保磁力と板状マルテンサイトの引 張軸への配向との関係を示すため, Fig. 9 に引張軸との成す 角度が任意の角度 $\alpha$ である時, 板状マルテンサイトを励磁 した場合の磁壁形成の模式図を示す。引張軸に励磁した場 合, 垂直方向に励磁した時と比べ, ブロッホ磁壁の面積に対 してピニングサイトである結晶粒界の密度が小さくなり, 保 磁力は減少する. 反対に垂直方向に励磁した場合, 保磁力は 増加する.つまり, 板状マルテンサイトおよび引張軸に対す る配向が, 磁壁の形成と移動に影響を与え, その結果, 保磁 力の角度依存性が現れたと考えられる. しかし, Fig. 8 の Sp.2については, 引張方向に対する明確な配向は見られな い. マルテンサイト体積分率が低い場合に打ける保磁力の振 
Magnetic Field $\mathbf{H}$

(a)

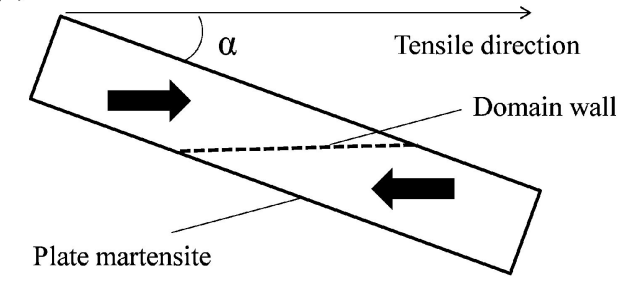

(b)

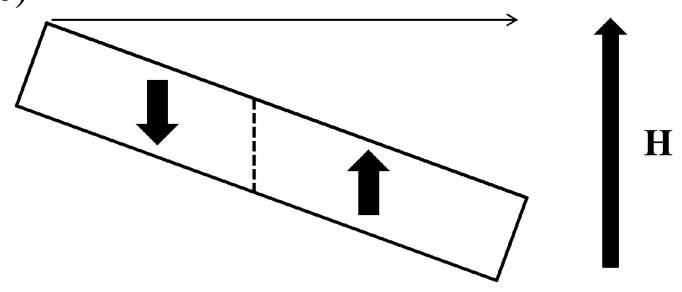

Fig. 9 Schematic diagram of domain wall formation for plate martensite. (a) Magnetization direction corresponds to tensile one. (b) Magnetization direction is perpendicular for tensile one.

る舞いについては, マルテンサイト相の形状と分布を含め, さらなる考察が必要である.

以上の点から, 応力方向に対する保磁力の角度依存性は, 結晶方位に依るものでなく，マルテンサイト相の形状とその 分布の影響を示唆しているものだと考えられる.

今後, 応力方向に対するマルテンサイト相の配向および分 布について定量的な解析も含め $\operatorname{EBSD}$ (電子線後方散乱回 折)などによる組織観察および磁区観察を通して微細組織と 磁気特性の関係についてさらに調査を進める予定である.

\section{5. 結言}

本研究では引張変形した SUS304 について引張方向に対 して励磁方向を変化させた場合の保磁力の角度依存性を系統 的に調査した。 その結果，以下の点を見出した.

（1）マルテンサイト体積分率の増加に伴い，保磁力が極大 を取った後, 減少する振る舞いが観測された。保磁力の減少 は，ブロッホ磁壁の面積に対するピニングサイト密度の減少 を示すため, 保磁力はマルテンサイト相の形状や分布等の形
態を強く反映していると考えられる.

(2) X 線回折による集合組織評価より，マルテンサイト 相は, 引張変形後, 非常に弱い集合組織が観測された。この 結果は，集合組織は磁気特性に強い影響を与えていないこと を示している.

（3）保磁力の角度依存性に扔いて，異方的な傾向が見出さ れたと共に，マルテンサイト体積分率に対して，その異方性 は顕著に変化しないことが分かった。この結果は，保磁力の 角度依存性にマルテンサイト相の異方的な形状と分布が反映 されていると考えられる.

以上のことから, 本研究により, 励磁方向を変化させた時の 保磁力の角度依存性に着目することで，マルテンサイト相の 量や粒のサイズだけでなく, マルテンサイト相の形態評価の 可能性を見出した.

本研究の議論において, 岩手大学の越後谷淳一客員教授, 菊池弘昭准教授より貴重なご意見, 実験に関して, 村上武技 官と福岡祐希氏から多くの助言を頂いた。ここに感謝を申し 上げる.

文献

1) P. L. Mangonon and G. Thomas: Metall. Trans. 1(1970) 15771586.

2) S. S. Hecker, M. G. Stout, K. P. Staudhammer and J. L. Smith: Metall. Trans. A 13(1982) 619-626.

3) R. Lagneborg: Acta Metall. 12(1964) 823-843.

4) S. Kobayahi, A. Saito, S. Takahashi, Y. Kamada and H. Kikuchi: Appl. Phys. Lett. 92(2008) 182508, 1-3.

5) S. Kobayahi, N. Kikuchi, S. Takahashi, Y. Kamada and H. Kikuchi: J. Appl. 108(2010) 043904, 1-8.

6) M. B. Stearns: Phys. Rev. 13(1976) 1183-1197.

7) K. Pawlik, J. Pospieeh and K. Lficke: Text Microstruct. 14-18 (1991) 25-30.

8) M. Ojima, Y. Adachi, Y. Tomota, K. Ikeda, T. Kamiyama and Y. Katada: Mater. Sci. Eng. A 527 (2009) 16-24.

9) V. Mertingera, E. Nagy, F. Tranta and J. Solyom: Mater. Sci. Eng. A 481-482 (2008) 718-722.

10) P. Haušild, K. Kolařik and M. Karlík: Mater. Des. 44(2013) $548-554$.

11) J. A. Pérez-Beniteza, J. Capó-Sánchez and L. R. Padovese: NDT\&E Int. 40(2007) 284-288.

12) F. Lecroisey and A. Pineau: Metall. Trans. 3(1972) 387-396.

13) K. Honda, S. Kaya and Y. Masuyama: Nature 117 (1926) 753754.

14) G. Herzer: Acta Mater. 33(1995) 1741-1756

15) R. M. Bozorth: Ferromagnetism, (IEEE, New York, 1978) and references therein. 